\title{
Protective Activity of Markhamia tomentosa (Benth.) K. Schum. (Bignoniaceae) Methanol Leaves Extract against D-Galactosamine/Lipopolysaccharide-Induced Acute Liver Injury in Mice
}

\author{
Roméo Joel Guemmogne Temdie ${ }^{1^{*}}$, Agathe Lambou Fotio², Flaure Donfack Metchi ${ }^{3}$, \\ Edwige Chiogo Vouffo Ymele ${ }^{3}$, Gilbert Thierry Nkoulou Tabi ${ }^{3}$, Théophile Dimo ${ }^{3}$ \\ ${ }^{1}$ Department of Biological Sciences, Faculty of Science, University of Ngaoundere, Ngaoundere, Cameroon \\ ${ }^{2}$ Department of Zoology and Animal Physiology, Faculty of Science, University of Buea, Buea, Cameroon \\ ${ }^{3}$ Department of Animal Biology and Physiology, Faculty of Science, University of Yaounde I, Yaounde, Cameroon \\ Email: *temdie2011@gmail.com
}

How to cite this paper: Temdie, R.J.G., Fotio, A.L., Metchi, F.D., Ymele, E.C.V., Tabi, G.T.N. and Dimo, T. (2020) Protective Activity of Markhamia tomentosa (Benth.) K. Schum. (Bignoniaceae) Methanol Leaves Extract against D-Galactosamine/Lipopolysaccharide-Induced Acute Liver Injury in Mice. Journal of Biosciences and Medicines, 8, 74-89.

https://doi.org/10.4236/jbm.2020.810008

Received: September 4, 2020

Accepted: October 18, 2020

Published: October 21, 2020

Copyright $\odot 2020$ by author(s) and Scientific Research Publishing Inc. This work is licensed under the Creative Commons Attribution International License (CC BY 4.0).

http://creativecommons.org/licenses/by/4.0/

\begin{abstract}
Markhamia tomentosa (Benth.) K. Schum. (Mt) is a Cameroonian medicinal plant, traditionally used to treat painful and inflammatory illness. This study aimed to examine the effects of methanol leaves extract (MLE) of $M t$ in D-galactosamine (D-GaIN)/lipopolysaccharide (LPS)-induced liver injury. The MLE (100 and $200 \mathrm{mg} / \mathrm{kg}$ ), Ascorbic acid $(10 \mathrm{mg} / \mathrm{kg}$ ) and distilled water were administered $12 \mathrm{~h}$ and $1 \mathrm{~h}$ before intraperitoneal injection of D-GaIN $(10 \mathrm{mg} / \mathrm{mouse}) / \mathrm{LPS}(0.1 \mu \mathrm{g} / \mathrm{g})$. Animals were sacrificed $6 \mathrm{~h}$ after D-GalN/LPS challenge. Liver injury was assessed biochemically by determination of aspartate aminotransferase (ASAT), alanine aminotransferase (ALAT), alkaline phosphatase (ALP), superoxide dismutase (SOD) and catalase activities. Malondialdehyde (MDA), reduced glutathione (GSH), nitrites, total protein and bilirubin levels were explored. Histopathological examination of liver tissue was also performed. Liver enzymes (ALAT, ASAT, ALP) activity, nitrites, MDA and bilirubin levels were increased, while protein level, SOD and catalase activities were significantly reduced by $\mathrm{D}-\mathrm{GalN} / \mathrm{LPS}$ administration. MLE (100 or $200 \mathrm{mg} / \mathrm{kg}$ ) protected mice against D-GalN/LPS-induced death. In addition, the plant extract significantly reduced ALAT and ALP activity, exhibiting $23.00 \%$ and $62.20 \%$ protection, respectively. SOD activity and total protein were significantly $(\mathrm{p}<0.05)$ increased by the plant extract. Total bilirubin and MDA levels were reduced $(\mathrm{p}<0.01)$ by $37.75 \%$ and $62.79 \%$, respectively in animal treated with MLE. Histological analysis of liver sections showed
\end{abstract}


that MLE (100 or $200 \mathrm{mg} / \mathrm{kg}$ ) protected mice against D-GaIN/LPS-induced liver injury. The obtained results showed that MLE of $M t$ may possess hepatoprotective effects. Protection afforded by MLE against D-GalN/LPS-induced fulminant liver injury may result from reduction of oxidative stress.

\section{Keywords}

Markhamia tomentosa, D-Galactosamine/Lipopolysaccharide, Oxidative Stress, Liver Injury

\section{Introduction}

There is an increasing interest in phytotherapy across the world [1]. Medicinal plants have been explored over years and some of currently available drugs are from plants' origin [2]. World Health Organization has pointed out the importance of research to support the development of traditional herbal medicine in delivering appropriate, safe and effective treatments [3].

About 800 species of trees, shrubs or lianas exist in the Bignoniaceae Juss. family [4]. They are largely found in tropics and few species are distributed in the temperate and sub-tropical regions [5]. They are mostly used for medicinal and ornamental purposes. Markhamia tomentosa, a tree of about $15 \mathrm{~m}$ high, found in the savannah forests, throughout West Africa and extending southward to Angola belongs to this family. M. tomentosa carries large yellow flowers in long terminal racemes and is quite decorative when flowering. Leaves are opposite with simple pinnately compound. In Cameroon, this plant is commonly known as "bougtoun" in Bayangam, "bobèdou" in Duala, "abbe" in Koosi or "mawelu" in Kpe [6].

The stem bark of $M$. tomentosa is used against chest pain while the leaf is used to cure headache, lumbago, oedema and gout [7]. Leaves and barks preparations are administered as rejuvenating, diuretic medicine for legs oedema and elephantiasis of the scrotum. These preparations are also used to treat canker, rheumatic pain, diseases of the respiratory tract and bouts of swamp-fever, constipation and fever [8] [9]. Ethnopharmacological data indicate some claimed therapeutic uses of this plant against snake bite/venom, sore eyes, heart pain [10], general pains, headache or backache [11]. M. tomentosa leaves are reported to cure diseases related to the reproductive system [12].

Previous studies showed that ethyl acetate, dichloromethane and methanol leaves extracts of $M$. tomentosa exhibited antioxidant and antimicrobial activities [10]. Phytochemical investigations revealed that saponins, tannins, anthraquinones, alkaloids, glycosides, cardiac glycosides, flavonoids and phenols are found in M. tomentosa methanol extract [13]. Eight compounds were identified in the ethyl acetate extract among which, 2-acetylnaphtho[2,3-b]furan-4,9-dione and 2-acetyl-6-methoxynaphtho[2,3-b]furan-4,9-dione exhibited potent antiprotozoal activity and high toxicity on myeloblast of rat skeletal muscle [14]. It 
was demonstrated that $M$. tomentosa leaf extracts possessed analgesic effects and the most potent was recorded with methanol leaf extract. This extract was able to inhibit carrageenan-induced paw oedema [13]. Anti-inflammatory activities of methanol leaves extract (MLE) were investigated on xylene, histamine and serotonin-induced acute inflammation, and on formalin and cotton pellet-induced chronic inflammation [15]. Anti-arthritic effects of methanol leaf extract of $M$. tomentosa on complete Freund's adjuvant induced arthritis were proved [16]. However, from the best of our knowledge, there is apparently no study available on MLE effects against experimental liver injury. This study was therefore undertaken to examine the hepatoprotective effects of MLE against acute D-GalN/LPS-induced fulminant liver injury in mice.

\section{Materials and Methods}

\subsection{Plant Material}

The leaves of Markhamia tomentosa were harvested in November 2009 in Yaounde, Cameroon. The plant was identified and authenticated by botanists of the Cameroon National Herbarium, by comparison to an existing voucher specimen registered under number 1974/SRFK.

\subsection{Method for Preparation of Plant Extract}

The air-dried leaves were pulverized in a motor-driven grinder and used to prepare extracts. A bioassay-guided extraction approach was used to determine the biological activities of different extracts. A sequential extraction was done based on the protocol described by Sosa et al. [17] with little modification. Five hundred grams of leaves powder of $M$. tomentosa were successively macerated for 72 $\mathrm{h}$ in hexane $(1000 \mathrm{~mL})$, dichloromethane $(1000 \mathrm{~mL})$, ethyl acetate $(1000 \mathrm{~mL})$ and methanol $(1000 \mathrm{~mL})$, and for $24 \mathrm{~h}$ in boiling distilled water $(1000 \mathrm{~mL})$. The macerate was air-dried and weighed after each extraction. Each filtrate was dried under reduced pressure, except water filtrate which was evaporated in an oven at $45^{\circ} \mathrm{C}$. The yields of hexane, ethyl acetate, dichloromethane, methanol and aqueous extracts were $0.11 \%, 1.40 \%, 1.31 \%, 6.30 \%$ and $5.30 \%$, respectively. Based on previous study [13], the methanol extract which was the most active extract was used for this experimentation and orally administered to animals.

\subsection{Chemicals}

Chemical substances used in the study were D-galactosamine hydrochloride (Sigma, USA), lipopolysaccharide (Sigma, USA), ascorbic acid (Fourrts, Chennai); Trichloroacetic acid, thiobarbituric acid, sulphanilamide, naphthylethylenediamide, phosphoric acid and DTNB (Sigma Aldrich, Germany); ALT, AST and bilirubin kits (Fortress Diagnostics Limited, UK) and ALP kits (Chronolab Systems, Spain).

\subsection{Animals}

Eight to ten weeks old male Swiss albino mice $(20-25 \mathrm{~g})$ used for this study 
were bred in the animal house of the Department of Animal Biology and Physiology, University of Yaounde I, Cameroon. The animals were grouped and housed in plastic cages $(\varnothing 40 \times 15 \mathrm{~cm})$ with no more than five animals per cage. These animals were kept under natural conditions (ambient temperature with 12:12 $\mathrm{h}$ light/dark cycle) and were allowed free access to standard commercial diet with water ad libitum. Animals were used and cared in agreement with internationally standard guidelines for animal use. Ethical clearance for using animals in the present study, was obtained from the Cameroon National Ethical Committee (Reg. $\mathrm{N}^{\circ}$ FWAIRD 0001954). Animals were fasted $12 \mathrm{~h}$ before the experiment.

\subsection{Experimental Design}

Thirty mice were randomly divided into five groups of 6 animals each, including normal saline + distilled water group, D-GalN/LPS + distilled water group, D-GalN/LPS + MLE (100 or $200 \mathrm{mg} / \mathrm{kg}$ ) groups and D-GalN/LPS + ascorbic acid $(10 \mathrm{mg} / \mathrm{kg})$ group. M. tomentosa methanol extract at the dose of 100 or 200 $\mathrm{mg} / \mathrm{kg}$ and ascorbic acid at the dose of $10 \mathrm{mg} / \mathrm{kg}$ were orally administered to D-GalN/LPS + MLE groups and D-GalN/LPS + ascorbic acid group, respectively, at $12 \mathrm{~h}$ and $1 \mathrm{~h}$ before induction of hepatitis. Normal saline and D-GalN/LPS groups were given only distilled water $(p . o$.). One hour after the treatment of mice, all animals except normal saline group received intraperitoneal injection of D-galactosamine hydrochloride (10 mg/mouse) and lipopolysaccharide $(0.1 \mu \mathrm{g} / \mathrm{g}$ of body weight). The animals were sacrificed by decapitation 6 hours after D-GaIN/LPS injection. Blood samples were collected in test tube and were used for serum preparation. The liver of each mice was removed, rinsed in normal saline solution. Two samples of the liver tissue were collected, one of them was homogenized ( $20 \%$ homogenate) in cold Tris- $\mathrm{HCl}$ buffer $(50 \mathrm{mM}, \mathrm{pH}$ 7.4) for biochemical analysis, while the other was plunged in $10 \%$ buffered formol for histological analysis. The number of animals' death was recorded and the percentage of protection $(P)$ was calculated by the relationship:

$$
P=(N s / N u) \times 100 ;
$$

where $N s$ is number of survival and $N u$ a number of mice used.

\subsection{Biochemical Analysis}

\subsubsection{Total Protein Determination}

Determination of total protein was performed according to the method of Biuret [18]. Liver homogenate $(20 \%, 10 \mu \mathrm{L})$ was added to $1.8 \mathrm{~mL}$ of normal saline $(\mathrm{NaCl}, 0.9 \%)$ and $1.5 \mathrm{~mL}$ of biuret reagent. The mixture was homogenized, paused for $20 \mathrm{~min}$ at $25^{\circ} \mathrm{C}$ and absorbance was read at $540 \mathrm{~nm}$. The amount of protein in each sample was determined from the bovine serum albumin calibration curve.

\subsubsection{Measurement of Liver Enzymes and Bilirubin}

The activity of alanine aminotransferase (ALAT) and aspartate aminotransferase 
(ASAT) in the sera was evaluated following the protocol of the commercial kit "Fortress Diagnostics Limited", UK. Alkaline phosphatase (ALP) activity in the mice's serum was carried out using commercial kit Chronolab Sys S.L., Spain. Total bilirubin in the serum was measured using commercial kit "Fortress Diagnostics Limited", UK.

\subsubsection{Measurement of Nitric Oxide (NO)/Nitrite}

The dosage of NO was done in the liver homogenate of $\mathrm{D}$-GaIN/LPS mice, indirectly through the determination of nitrite by Griess reagent (1\% sulfanilamide and $0.1 \%$ naphthyl ethylene diamine in $2.5 \%$ phosphoric acid) [19]. The absorbance of the preparation was measured at $570 \mathrm{~nm}$ with the spectrophotometer (Genesis 20) and nitrite level was determined by using the sodium nitrite standard curve.

\subsubsection{Malondialdehyde (MDA) Determination}

MDA as an indicator of lipid peroxidation in tissues, was determined in the liver of mice by the method described by Wilbur et al. [20]. Tissue homogenate (1 ml) were added to $0.5 \mathrm{ml}$ of trichloroacetic acid (20\%) and $1 \mathrm{ml}$ of thiobarbituric acid $(0.67 \%)$. The mixture was allowed to react for $10 \mathrm{~min}$ at high temperature $\left(90^{\circ} \mathrm{C}\right.$, water bath). The mixture was centrifuged and the absorbance of the supernatant measured at $530 \mathrm{~nm}$. The concentration of MDA was quantified with the extinction coefficient of $1.56 \times 10^{5} \mathrm{M}^{-1} \cdot \mathrm{cm}^{-1}$ and expressed as $\mu \mathrm{M}$ of MDA per $g$ of protein.

\subsubsection{Reduced Glutathione Level}

The assay of reduced glutathione was performed following the protocol described by Ellman [21]. Liver tissue homogenates $(10 \mu \mathrm{L})$ were added to Ellman's reagent $(1500 \mu \mathrm{L})$. The mixture was then incubated for $1 \mathrm{~h}$ at room temperature and the absorbance was determined at $412 \mathrm{~nm}$. The amount of reduced glutathione $(\mathrm{mol} / \mathrm{mg}$ of protein) was calculated with molar extinction coefficient $(13,600 / \mathrm{M} \times \mathrm{cm})$

\subsubsection{Catalase Activity}

Catalase activity was evaluated according to the protocol of Sinha [22]. Briefly, $25 \mu \mathrm{L}$ of homogenate and $375 \mu \mathrm{L}$ of phosphate buffer $(0.1 \mathrm{M}, \mathrm{pH} 7.5)$ were mixed. Hydrogen peroxide solution $(100 \mu \mathrm{L}, 50 \mathrm{mM})$ was introduced in the mixture and the reaction was stopped one minute later by adding $1 \mathrm{~mL}$ of dichromate/pure glacial acetic acid. All tubes were heated $\left(100^{\circ} \mathrm{C}\right)$ for 10 minutes. After cooling, the absorbance was read at $620 \mathrm{~nm}$, catalase activity was determined using the calibration curve and expressed as mmol of $\mathrm{H}_{2} \mathrm{O}_{2} / \mathrm{min} / \mathrm{mg}$ of protein.

\subsubsection{Superoxyde Dismutase (SOD) Activity}

The activity of superoxyde dismutase was evaluated according to the protocol established by Misra and Fridovich [23]. Liver homogenate $(67 \mu \mathrm{L})$ and carbonate buffer $(833 \mu \mathrm{L}, 50 \mathrm{mM}, \mathrm{pH} 10.2)$ were added to adrenaline solution $(100 \mu \mathrm{L}$, 
$0.3 \mathrm{mM})$. The absorbance of the preparation was read at $480 \mathrm{~nm}, 20 \mathrm{~s}$ and $80 \mathrm{~s}$ after introduction of adrenaline in the medium. The specific activity of SOD was expressed as SOD unit/mg of protein.

\subsection{Histopathological Analysis}

The liver samples previously kept in buffered formol (10\%) were subjected to the following histological techniques. After dehydration, liver samples were embedded in paraffin (melting point: $56^{\circ} \mathrm{C} \pm 2^{\circ} \mathrm{C}$ ) to form blocks, $5 \mu \mathrm{m}$ thick sections from each sample were stained with haematoxylin-eosin and observed under light microscope (Olympus, GHBS, Japan).

\subsection{Statistical Analysis}

Values are presented as mean \pm standard error by mean (SEM). Statistical differences between control and treated groups were calculated by analysis of variance (ANOVA). Dunnett's post hoc test was also applied using GraphPad InStat Software. Values were considered significantly different if $\mathrm{p}<0.05$.

\section{Results}

\subsection{Effect of M. tomentosa Methanol Extract on Mortality Rate of Mice Treated with D-GaIN/LPS}

One hour after injection of D-galactosamine/lipopolysaccharide (D-GaIN/LPS), the mortality rate was $16.67 \%$ in D-GaIN/LPS + distilled water treated mice, two hours after it was $33.33 \%$ before it stabilized $4 \mathrm{~h}$ later up to the end of the study at $50.00 \%$. In group of mice treated with $M$. tomentosa methanol extract (100 or $200 \mathrm{mg} / \mathrm{kg}$ ), $3 \mathrm{~h}$ after injection of D-GaIN/LPS, the mortality rate was $0.00 \%$ and $16.67 \%$, five hours afterward it was $16.67 \%$ and $33.33 \%$, respectively, and remained unchanged until the end of experiment. Therefore, the protective effect of $M$. tomentosa methanol extract (100 or $200 \mathrm{mg} / \mathrm{kg}$ ) was $83.33 \%$ and $66.67 \%$, respectively. No death was recorded in animals pre-treated with ascorbic acid $(10 \mathrm{mg} / \mathrm{kg})$, which scored a $100 \%$ protection.

\subsection{Evaluation of Hepatic Function}

\subsubsection{Effect of M. tomentosa Methanol Extract on Liver Enzymes (ALAT, ASAT and ALP) Activity}

An increasing activity of alanine aminotransferase (ALAT), aspartate aminotransferase (ASAT) and alkaline phosphatase (ALP), of 48.13\% $(\mathrm{p}<0.01)$, $42.87 \%(\mathrm{p}<0.05)$ and $162.75 \%(\mathrm{p}<0.01)$, respectively, compared to normal group, was registered $6 \mathrm{~h}$ after administration of $\mathrm{D}$-GaIN/LPS to mice. Treatment of animals with $M$. tomentosa methanol extract (100 or $200 \mathrm{mg} / \mathrm{kg}$ ) or ascorbic acid $(10 \mathrm{mg} / \mathrm{kg})$ resulted in a decrease in ALAT, ASAT and ALP activity. The methanol extract $(100 \mathrm{mg} / \mathrm{kg})$ induced a significant inhibition of ALAT activity by $23.00 \%$. The activity of ALP was significantly decreased following administration of methanol extract of $M$. tomentosa. The plant extract exhibited $51.55 \%$ and $62.20 \%$ inhibition of ALP activity at $100 \mathrm{mg} / \mathrm{kg}$ and 200 
$\mathrm{mg} / \mathrm{kg}$, respectively. Ascorbic acid $(10 \mathrm{mg} / \mathrm{kg})$ significantly reduced (60.87\%) ALP activity. Treatment with the methanol extract (100 or $200 \mathrm{mg} / \mathrm{kg}$ ) or ascorbic acid kept ASAT activity close to that of normal mice (Figure 1).

\subsubsection{Effect of M. tomentosa Methanol Extract on Total Protein and Bilirubin Levels}

Administration of LPS to D-GaIN sensitised mice decreased total protein liver level by $66.56 \%(\mathrm{p}<0.01)$, compared to normal control. Plant extract increased $(137.88 \%$ and $101.02 \%)$ protein level $(\mathrm{p}<0.05)$ at 100 and $200 \mathrm{mg} / \mathrm{kg}$, respectively, compared to D-GaIN/LPS-treated mice (Figure 2(A)). Pre-treatment of mice with ascorbic acid $(10 \mathrm{mg} / \mathrm{kg})$ did not cause a significant increment in total protein content, compared to D-GaIN/LPS mice.

D-GaIN/LPS induced a significant $(\mathrm{p}<0.01)$ increase $(94.81 \%)$ of total bilirubin, compared to normal animals. M. tomentosa extract (100 or $200 \mathrm{mg} / \mathrm{kg}$ ) as well as ascorbic acid $(10 \mathrm{mg} / \mathrm{kg})$ exhibited $36.02 \%, 37.75 \%$ and $43.32 \%$ inhibition of total bilirubin level, respectively, compared to D-GaIN/LPS-treated mice (Figure 2(B)).

\subsection{Evaluation of Oxidative Stress Parameters}

\subsubsection{Effect of M. tomentosa Methanol Extract on Nitrite, MDA and Glutathione Levels}

Nitrite level significantly increased from $0.180 \pm 0.085 \mathrm{mM}$ in normal mice to $0.886 \pm 0.105 \mathrm{mM}, 6$ hours after D-GaIN/LPS injection. Pre-treatment with ascorbic acid $(10 \mathrm{mg} / \mathrm{kg})$ induced a non-significant reduction of nitrite level, compared to D-GaIN/LPS mice. Pre-treatment of mice with $M$. tomentosa methanol extract $(100$ or $200 \mathrm{mg} / \mathrm{kg}$ ) did not change the liver nitrite content, compared to D-GaIN/LPS group (Figure 3(A)).

Malondialdehyde level (MDA) increased in significant manner from $18.23 \pm$

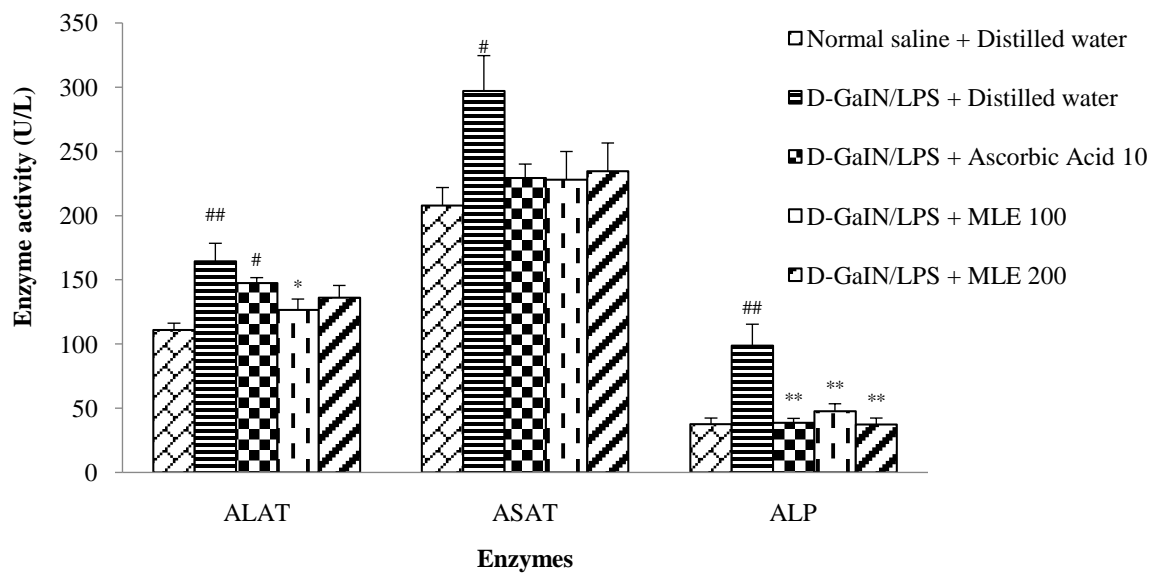

Figure 1. Effect of $M$. tomentosa methanol extract on ALAT, ASAT and ALP serum activity in $\mathrm{D}$-GalN/LPS-treated in mice. Results are expressed as mean $\pm \mathrm{SEM}, \mathrm{n}=6 .{ }^{*} \mathrm{p}<$ $0.05 ;{ }^{* *} \mathrm{P}<0.01$ significantly different from the $\mathrm{D}$-Gain/LPS group. ${ }^{*} \mathrm{p}<0.05,{ }^{* *} \mathrm{p}<0.01$ significantly different from normal group. MLE (100 or 200) = methanol leaf extract of M. tomentosa (100 or $200 \mathrm{mg} / \mathrm{kg})$. Ascorbic acid $10=$ ascorbic acid $(10 \mathrm{mg} / \mathrm{kg})$. 

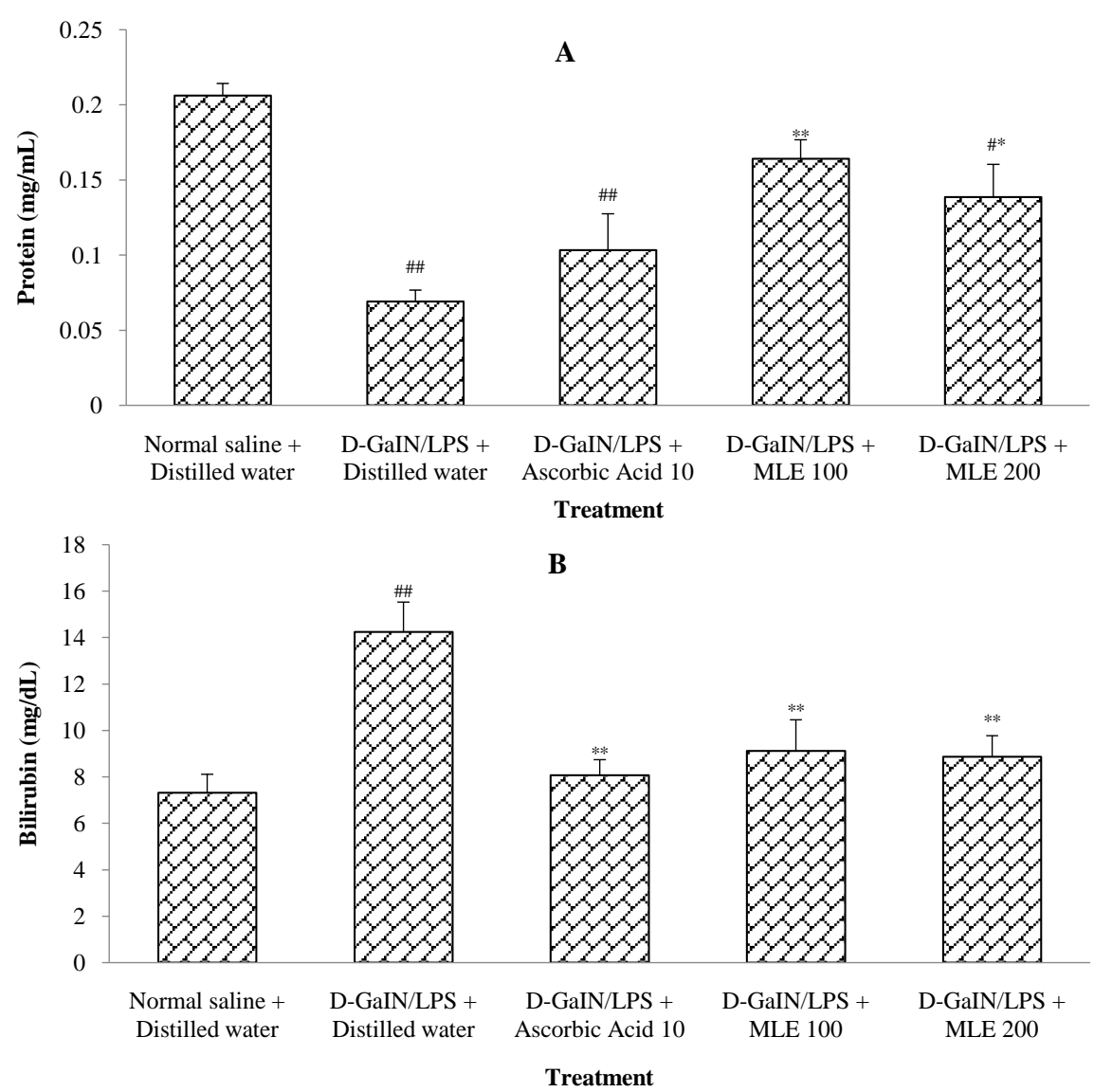

Figure 2. Effect of M. tomentosa methanol extract on total protein (A) and bilirubin (B) serum levels in $\mathrm{D}$-GalN/LPS-induced hepatitis in mice. Results are presented as mean \pm $\mathrm{SEM}, \mathrm{n}=6 .{ }^{*} \mathrm{p}<0.05 ;{ }^{* *} \mathrm{P}<0.01$ significantly different compared to $\mathrm{D}-\mathrm{Gain} / \mathrm{LPS}$ group. ${ }^{\#} \mathrm{p}<0.05,{ }^{\# \#} \mathrm{p}<0.01$ significantly different compared to normal group. MLE (100 or 200) $=$ methanol leaf extract of $M$. tomentosa $(100$ or $200 \mathrm{mg} / \mathrm{kg})$. Ascorbic acid $10=$ ascorbic acid $(10 \mathrm{mg} / \mathrm{kg})$.

$2.18 \mathrm{nmol} / \mathrm{mg}$ of protein in the liver of normal control mice to $69.14 \pm 5.95$ $\mathrm{nmol} / \mathrm{mg}$ in the liver of $\mathrm{D}$-GaIN/LPS group. M. tomentosa methanol extract significantly inhibited MDA production, exhibiting $62.79 \%$ and $48.52 \%$ protection at 100 and $200 \mathrm{mg} / \mathrm{kg}$, respectively, compared to D-GaIN/LPS animals. Ascorbic acid $(10 \mathrm{mg} / \mathrm{kg})$ administration significantly decreased MDA level by $61.14 \%$ compared to D-GaIN/LPS treated mice (Figure 3(B)).

Administration of $M$. tomentosa extract or ascorbic acid did not change reduced glutathione level compared to D-GaIN/LPS treated group and normal mice (Figure 3(C)).

\subsubsection{Effect of M. tomentosa Methanol Extract on Catalase and SOD Activities}

A significant reduction of catalase activity $(67.84 \%)$ was recorded $6 \mathrm{~h}$ following D-GaIN/LPS administration, compared to normal mice. Administration of ascorbic acid $(10 \mathrm{mg} / \mathrm{kg})$ triggered an increase in catalase activity compared to D-GaIN/LPS mice. Administration of M. tomentosa methanol extract (100 or 

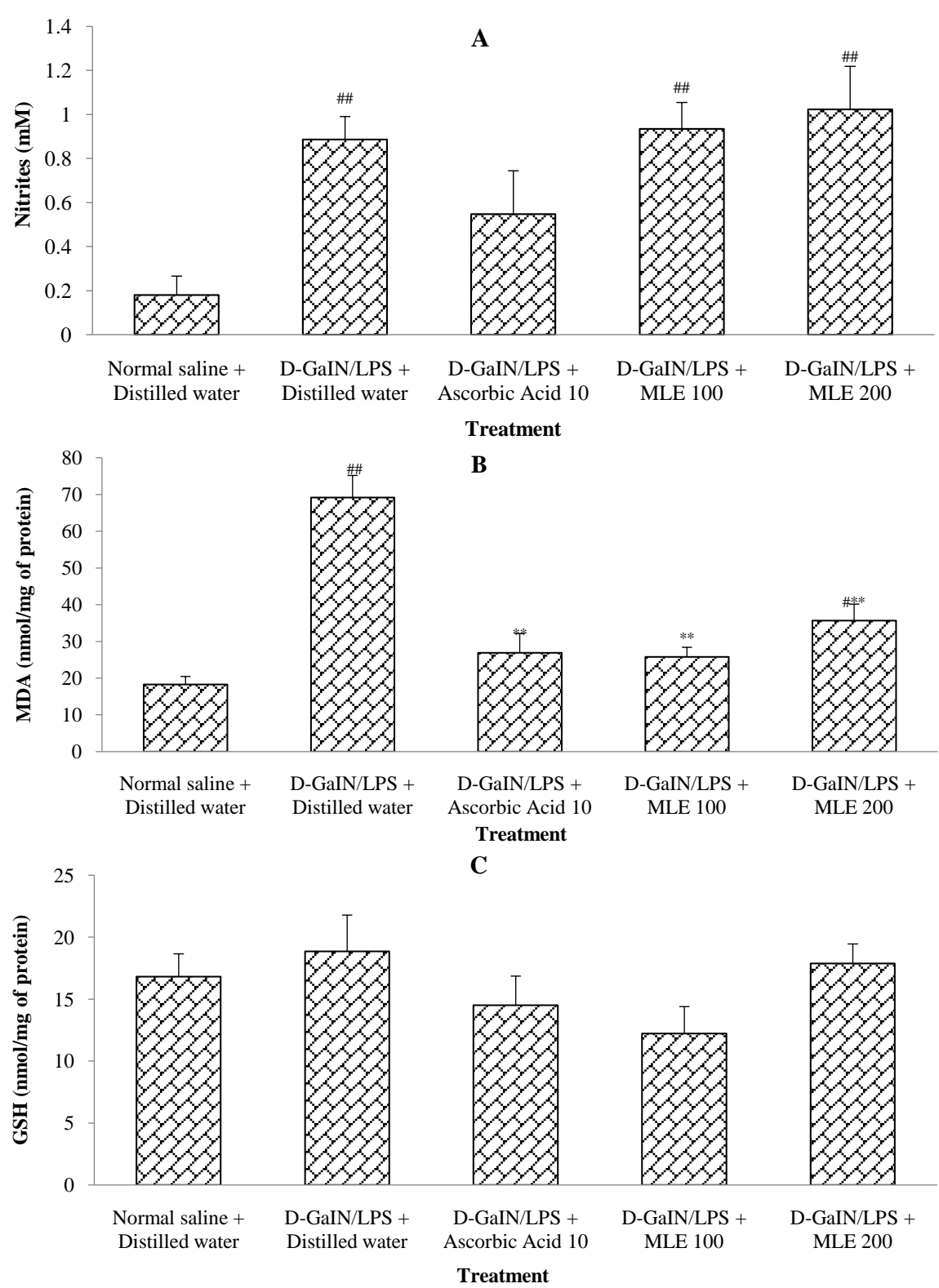

Figure 3. Effect of $M$. tomentosa methanol extract on nitrite (A), MDA (B) and reduced glutathione $(\mathrm{C})$ levels of $\mathrm{D}$-GalN/LPS-treated mice. Results are expressed as mean \pm SEM, $\mathrm{n}=6$. ${ }^{* *} \mathrm{P}<0.01$ significantly different compared to D-Gain/LPS group. ${ }^{\#} \mathrm{p}<0.05$, ${ }^{* \#} \mathrm{p}<$ 0.01 significantly different compared to normal group. MLE $(100$ or 200$)=$ methanol leaf extract of M. tomentosa (100 or $200 \mathrm{mg} / \mathrm{kg})$. Ascorbic acid $10=$ ascorbic acid $(10 \mathrm{mg} / \mathrm{kg})$.

$200 \mathrm{mg} / \mathrm{kg}$ ) to animals did not induced any significant change in catalase activity in liver tissue, compared to D-Gain/LPS group (Figure 4(A)).

Injection of $\mathrm{D}-\mathrm{GaIN} / \mathrm{LPS}$ resulted $6 \mathrm{~h}$ later in a significant $(\mathrm{p}<0.01)$ decrease (94.66\%) of liver superoxide dismutase (SOD) activity, compared to normal mice. M. tomentosa methanol extract $(200 \mathrm{mg} / \mathrm{kg})$ and ascorbic acid $(10 \mathrm{mg} / \mathrm{kg})$ significantly $(\mathrm{p}<0.01)$ increase SOD activity, from $16.17 \pm 2.40$ units $/ \mathrm{mg}$ of protein in D-Gain/LPS mice to $127.46 \pm 23.56 \mathrm{unit} / \mathrm{mg}$ protein and $250.60 \pm$ $42.38 \mathrm{unit} / \mathrm{mg}$ of protein, respectively. However, pre-treatment of D-GaIN/LPS 


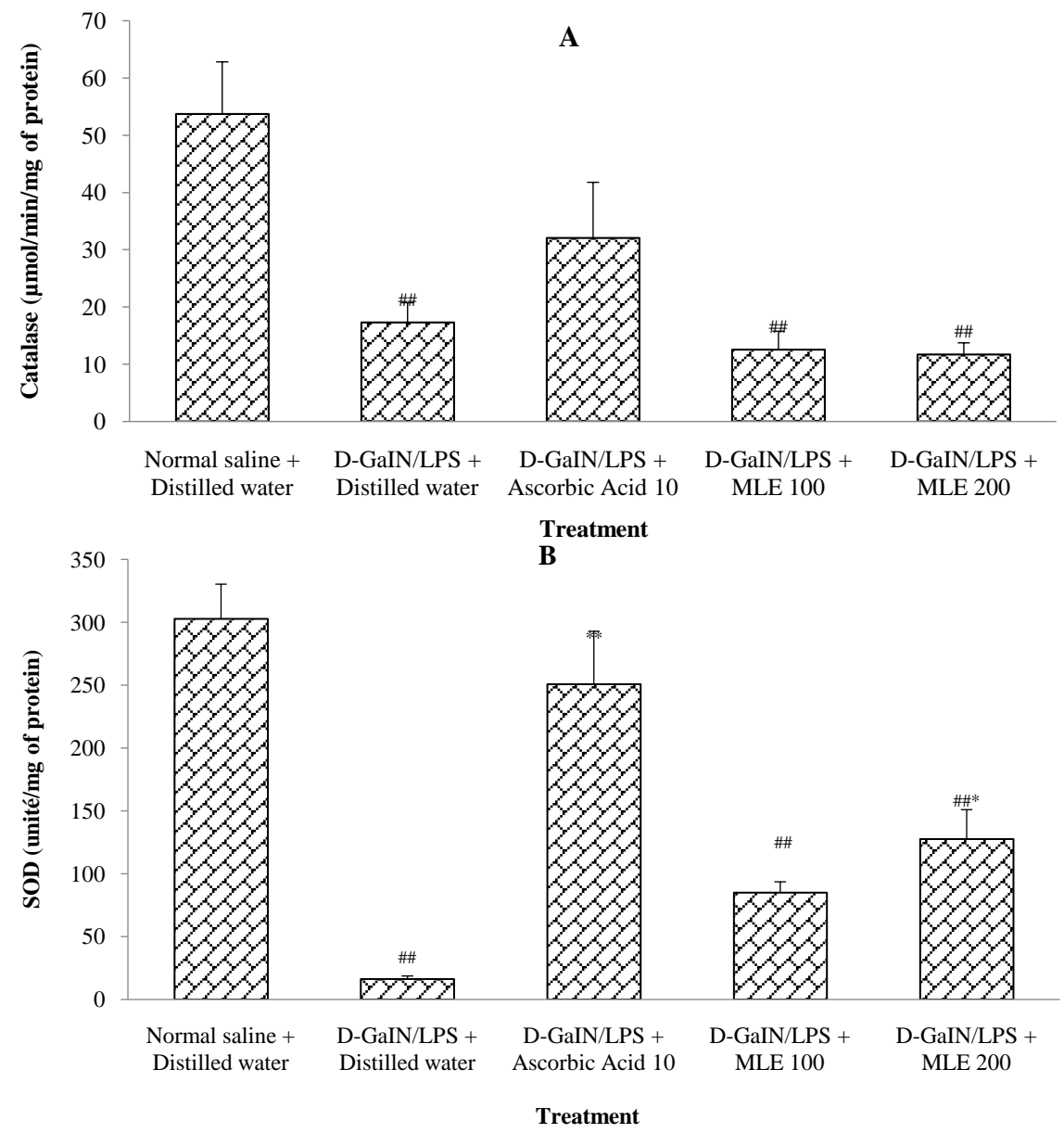

Figure 4. Effect of M. tomentosa methanol extract on catalase (A) and SOD (B) activities in the liver of $\mathrm{D}$-GalN/LPS treated mice. Results are expressed as mean $\pm \mathrm{SEM}, \mathrm{n}=6$. ${ }^{* \star \mathrm{P}}$ $<0.01$ significantly different from the $\mathrm{D}$-Gain/LPS group. ${ }^{*} \mathrm{p}<0.05,{ }^{\# \#} \mathrm{p}<0.01$ significantly different compared to normal group. MLE (100 or 200) = methanol leaf extract of M. tomentosa (100 or $200 \mathrm{mg} / \mathrm{kg})$. Ascorbic acid $10=$ ascorbic acid $(10 \mathrm{mg} / \mathrm{kg})$.

animals with plant extract failed to completely restore SOD activity to normal level (Figure 4(B)).

\subsubsection{Effect of M. tomentosa Methanol Extract on D-GaIN/LPS-Induced Liver Damage}

Histological examination of the liver of healthy mice showed a steady liver architecture highlighting the veins, arteries and normal liver parenchyma (Figure 5(A)). The histological structure of D-GaIN/LPS mice liver showed a liver parenchyma with many abnormalities such as haemorrhage, hepatocyte steatosis, vascular congestion and many leukocyte infiltrations surrounding blood vessels (Figure 5(B)). Treatment of mice by plant extract (100 or $200 \mathrm{mg} / \mathrm{kg}$ ) resulted in an improvement of mice liver structure with low leukocyte infiltration, a reduction of steatosis and haemorrhage, compared to D-GaIN/LPS animal (Figure 5(C) and Figure 5(D)). Liver tissue of mice treated with ascorbic acid (10 $\mathrm{mg} / \mathrm{kg}$ ) was less damaged compared to D-GaIN/LPS mice, but was comparable to that of normal mice (Figure 5(E)). 


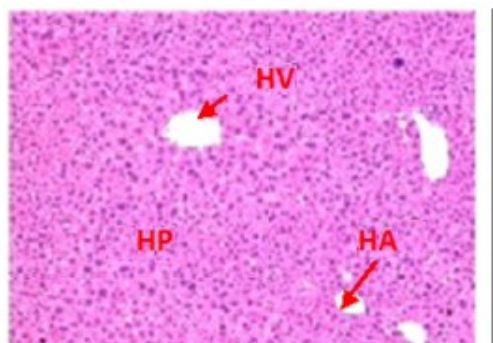

(A)

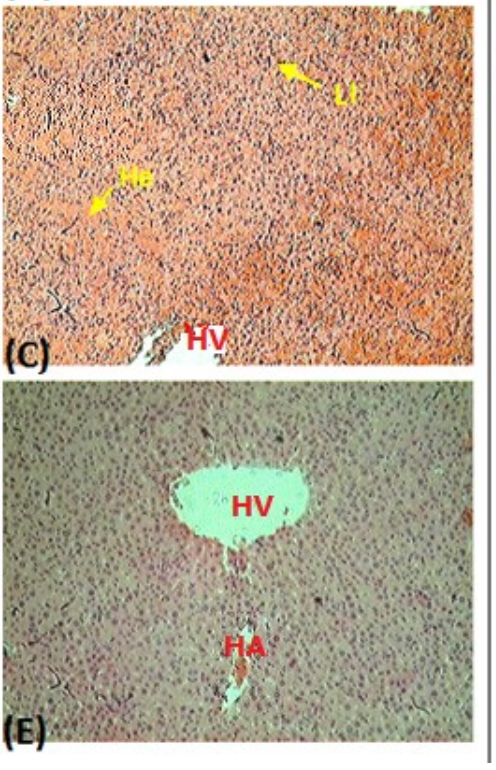

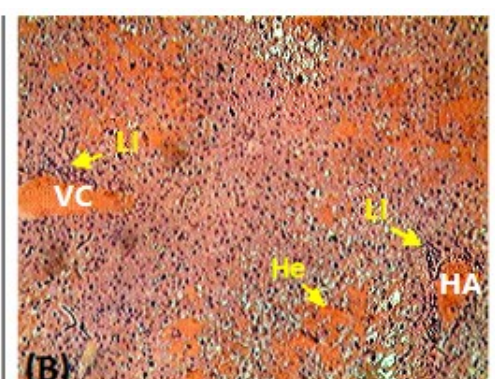

(B)

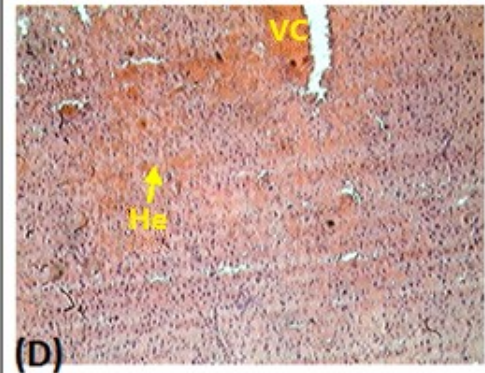

(D)

Figure 5. Effect of $M$. tomentosa methanol extract on D-GaIN/LPS-induced liver damage. Haematoxylin-eosin $(\times 100)$. (A) Distilled water; (B) D-GaIN/LPS + Distilled water; (C) D-GaIN/LPS + MLE (100 mg/kg); (D) D-GaIN/LPS + MLE (200 mg/kg); (E) D-GaIN/LPS + Ascorbic acid (10 mg/kg); VC: vascular congestion; HA: hepatic artery; HP: hepatic parenchyma; HV: hepatic vein. LI: leukocyte infiltration. He: haemorrhage.

\section{Discussion}

We investigated the hepatoprotective effects of Markhamia tomentosa methanol leaves extract on D-galactosamine/lipopolysaccharide-induced hepatitis in mice. Results showed that, the methanol extract of $M$. tomentosa reduced liver damages caused by D-GaIN/LPS.

Hepatitis induced by injection of D-galactosamine (D-GalN) and lipopolysaccharide (LPS) is a classical model of acute hepatitis well studied. D-GalN is a sugar selectively metabolized by hepatocytes. This amino sugar causes a depletion of uridine triphosphate pool and therefore inhibits hepatic synthesis of macromolecules like RNA, proteins and glycogen [24]. This amino sugar induces liver damage and also increases the production of free radical species in hepatocytes [25]. D-GalN causes liver damage that closely resembles the human viral hepatitis. The hepatitis induced by galactosamine is characterized by increased levels of bilirubin [26]. When D-GalN is used together with LPS they enhance the development of lethal liver injury or even death of animals. Liver macrophages, when activated by LPS, release a variety of inflammatory cytokines. 
D-GalN/LPS induces excessive production of pro-inflammatory mediators like TNF- $\alpha$ which is released primarily by Kupffer cells and intervenes in the process of apoptosis and necrosis of hepatocytes [27]. Stimulation of inducible nitric oxide synthase by D-GaIN/LPS lead to massive production of NO which contributes to pathogenesis of septic shock and inflammatory diseases such as hepatitis [28]. Reactive oxygen species and other free radicals generally play an important role in the development of many diseases including hepatitis [29].

In this study, administration of D-GaIN/LPS resulted in a significant increase in bilirubin levels compared to the normal. Hepatocytes synthesize bilirubin by catabolism of haemoglobin and excrete it by conjugation reactions with glucuronic acid. This reaction eases elimination of bilirubin in bile or urine. Thus, any increase of bilirubin in the body would indicate a damage of liver function [30]. Treatment of mice with $M$. tomentosa leaves extract and ascorbic acid significantly reduced hepatic bilirubin levels compared to D-GaIN/LPS mice. These results suggest that these substances have preventive effects against D-GaIN/LPS-induced toxicity.

Hepatitis induced by LPS/D-GalN is characterized by an increased activity of ALAT and ASAT [31]. An increase activity of transaminase is a sign of hepatocytes deterioration [32]. Our results showed a significant increase in transaminase activity after induction of hepatitis, in comparison to normal mice. A significant reduction of hepatic protein levels was observed in D-GaIN/LPS treated mice. A decrease of total protein content of the liver is generally associated with alteration of liver anabolic function [33]. Mice treated by methanol leaves extract $(100 \mathrm{mg} / \mathrm{kg})$ displayed a significant reduction of ALAT activity and kept ASAT activity close to the normal. A significant increase in hepatic protein levels was also observed after administration of the plant extract to mice. These results suggest that MLE contain compounds that protect hepatocytes against toxic effects of D-GaIN/LPS. In this study, D-GaIN/LPS caused increase activity of ALP, compared to normal animals. Administration MLE to mice significantly reduced ALP activity compared to D-GaIN/LPS mice, suggesting that MLE preserves from the harmful effects of GaIN/LPS in mice liver.

Injection of D-GalN/LPS induces overproduction of inflammatory substances like TNF- $\alpha$, IL- 1 and NO. These mediators are involved in apoptosis or necrosis of hepatocytes [27] [34]. Overproduction of NO can activate nuclear factor kappa $\mathrm{B}$, which will induce the expression of pro-inflammatory mediators (TNF- $\alpha$, IL-1) and cause oedema by increasing vascular permeability [35] [36]. It also contributes to peroxynitrite production, causing nitration and oxidation of proteins, blockage of mitochondrial function, DNA damage, cell apoptosis or necrosis associated to inflammatory diseases [37] [38]. Nitrite level was significantly increased in hepatic tissue of D-GaIN/LPS mice compared to normal animals. Pre-treatment of mice with MLE did not significantly change nitrite level in D-GalN/LPS-treated mice. We have previously demonstrated that MLE significantly decreased, in dose-dependent manner, serum, spleen and liver nitrite content in formalin-induced chronic inflammation [15]. These results 
may be due to subacute treatment with MLE. No structural alteration was observed in the liver parenchyma of normal mice. However, D-GaIN/LPS induced haemorrhage, steatosis, necrosis and leukocyte infiltration in liver tissue. Pre-treatment with MLE and ascorbic acid reduced damage caused by D-GaIN/LPS in liver tissue, which was similar to that of normal mice. These observations suggest the protecting action of MLE against D-GalN/LPS induced liver damage.

It has been reported that, free radicals species interact with polyunsaturated fatty acids and increase lipid peroxidation, leading to production of malondialdehyde (MDA), which is commonly used as an indicator of liver damage [31]. Results showed an elevated rate of MDA in liver tissue of mice treated with D-GaIN/LPS. Treatment with MLE significantly decreased MDA levels, suggesting an antioxidant activity of this extract.

Superoxide dismutase (SOD), catalase and glutathione peroxidase are the main antioxidant enzymes that protect the body against oxidant stress [39]. SOD limits accumulation of superoxide anion $\left(\mathrm{O}^{2-}\right)$ and generates hydrogen peroxide $\left(\mathrm{H}_{2} \mathrm{O}_{2}\right)$ involved in production of hydroxyl radical $\left(\mathrm{HO}^{-}\right)$by Fenton reaction. Catalase catalyses the conversion of $\mathrm{H}_{2} \mathrm{O}_{2}$ into oxygen $\left(\mathrm{O}^{2}\right)$ and water $\left(\mathrm{H}_{2} \mathrm{O}\right)$. Glutathione peroxidase uses reduced glutathione as a substrate to degrade organic hydroperoxydes and $\mathrm{H}_{2} \mathrm{O}_{2}$ into harmless compounds. These enzymes control the balance between pro-oxidant and antioxidant processes. MLE (200 $\mathrm{mg} / \mathrm{kg}$ ) and ascorbic acid instigated a significant raise in SOD activity. These results show that MLE would have an inhibitory effect on pro-oxidant process.

\section{Conclusion}

The aim of the present work was to assess the effect of Markhamia tomentosa methanol leaves extract on D-galactosamine/lipopolysaccharide-induced acute liver injury in mice. Administration of plant extract before injection of D-GaIN/LPS reduced ALAT and ALP serum activity, bilirubin and MDA liver levels and increased SOD activity and total protein level, compared to animal treated with D-GaIN/LPS and vehicle. Histological analysis also revealed that MLE prevented D-GaIN/LPS to induced liver injury in mice. The present study demonstrates that Markhamia tomentosa methanol extract may have protective effects against hepatitis. MLE protects against D-GaIN/LPS-induced fulminant hepatic failure through inhibition of tissue peroxidation, reduction of oxidant tress and thus, prevents tissue damage. MLE could offer an alternative treatment for acute liver inflammation. The precise mechanisms of action of MLE and its ability to provide a preventive effect during $\mathrm{D}$-GaIN/LPS-mediated liver failure are still to be investigated.

\section{Acknowledgements}

The authors would like to thank Dr. Fodouop Chegaing Simeon and Dr. Fokam Tagne Michel Archange for revising this article. 
This work was supported by the International Foundation for Science (IFS) through research grant number F/5548-1.

\section{Conflicts of Interest}

The authors certify that they have no affiliation with, or financial involvement in any organization with a direct financial interest in the subject matter or materials discussed in the manuscript.

\section{References}

[1] WHO (2002) World Health Organization Launches the First Global Strategy on Traditional and Alternative Medicine. http://www.who.int/mediacentre/news/releases/release38/en/

[2] Pietro, E. (2002) Antimicrobial Resistance and Susceptibility Testing: An Evergreen Topic. Journal of Antimicrobial Chemotherapy, 50, 1-4. https://doi.org/10.1093/jac/dkf093

[3] WHO (2008) World Health Organization Beijing Declaration. http://www.who.int/medicines/areas/traditional/congress/beijing_declaration/en/

[4] Watson, L. and Dallwitz, M. (1992) The Families of Flowering Plants: Descriptions, Illustrations, Identification, and Information Retrieval.

http://www.worldcat.org/title/families-of-flowering-plants-descriptions-illustration s-identification-and-information-retrieval/oclc/34189020

[5] Ghazanfar, S.A. (1989) Savanna Plants. An Illustrated Guide, Illustrate, Macmillan Educational Corp, Basingstoke.

[6] Burkill, H.M. (2002) The Useful Plants of West Tropical Africa. Royal Botanic Gardens, Kew.

[7] Arbonnier, M. (2000) Arbres, arbustes et lianes des zones sèches d'Afrique de l'Ouest. 2eme ed, CIRAD, MNHN, Montpellier, $541 \mathrm{p}$.

[8] Bouquet, A. and Debray, M. (1974) Plantes Medicinales de Cote d'Ivoire. O.R.S.T.O.M. Office de la recherche scientifique et technique outre-mer, Paris.

[9] Irvine, F. (1961) Woody Plants of Ghana. Oxford University Press, London.

[10] Adebajo, A., Aladesanmi, A., Iwalewa, E., Akinkunmi, E., Taiwo, B., Olorunmola, F. and Lamikanr, A. (2007) Antimicrobial and Antioxidant Activities of Some Nigerian Medicinal Plants. African Journal of Traditional Complementary and Alternative Medicines, 4, 173-184. https://doi.org/10.4314/ajtcam.v4i2.31206

[11] Ainslie, J.R. (1937) List of Plants Used in Native Medicine in Nigeria. Oxford University Press, Institute Paper, No. 7, London.

[12] Bep, O. (1986) Medicinal Plants of Tropical West Africa. Cambridge University Press, Cambridge.

[13] Temdie, G., Fotio, A.L., Dimo, T., Beppe, J. and Tsague, M. (2012) Analgesic and Anti-Inflammatory Effects of Extracts from the Leaves of Markhamia tomentosa (Benth.) K. Schum. (Bignoniaceae). Pharmacologia, 3, 565-573. https://doi.org/10.5567/pharmacologia.2012.565.573

[14] Tantangmo, F., Lenta, B.N., Boyom, F.F., Ngouela, S., Kaiser, M., Tsamo, E., Weniger, B., Rosenthal, P.J. and Vonthron-Senecheau, C. (2010) Antiprotozoal Activities of Some Constituents of Markhamia tomentosa (Bignoniaceae). Annals of Tropical Medicine \& Parasitology, 104, 391-398. 
https://doi.org/10.1179/136485910X12743554760180

[15] Temdie, R.J.G., Fotio, A.L. and Dimo, T. (2012) Acute and Chronic Anti-Inflammatory Effects of the Methanol Leaf Extract of Markhamia tomentosa (Benth.) K. Schum. (Bignoniaceae). Journal of Scientific Research in Pharmacy, 1, $12-18$.

[16] Temdie, G., Metchi, F., Ymele, E., Minoue, K. and Dimo, T. (2016) The Effects of the Methanol Leaf Extract of Markhamia Tomentosa (Benth.) K. Schum. (Bignoniaceae) on Arthritis Induced by Complete Freund's Adjuvant in Rats. World Journal of Pharmacy and Pharmaceutical Sciences, 5, 79-92.

[17] Sosa, A., Fusco, M.R., Rossomando, P., Juárez, A., Robles, S., Petenatti, E. and Pelzer, L. (2011) Anti-Inflammatory Properties from Isolated Compounds of Cyclolepis genistoides. Pharmaceutical Biology, 49, 675-678. https://doi.org/10.3109/13880200903431467

[18] Gornall, A.G., Bardawill, C.J. and David, M.M. (1949) Determination of Serum Proteins by Means of the Biuret Reaction. Journal of Biological Chemistry, 177, 751-766.

[19] Fotio, A.L., Dimo, T., Nguelefack, T.B., Dzeufiet, P.D., Ngo, Lemba, E., Temdie, R.J., Ngueguim, F., Olleros, M.L., Vesin, D., Dongo, E., Kamtchouing, P. and Garcia, I. (2009) Acute and Chronic Anti-Inflammatory Properties of the Stem Bark Aqueous and Methanol Extracts of Sclerocarya Birrea (Anacardiaceae). Inflammopharmacology, 17, 229-237. https://doi.org/10.1007/s10787-009-0011-2

[20] Wilbur, K.M., Bernheim, F. and Shapiro, O.W. (1949) Determination of Lipid Peroxidation. Archives of Biochemistry, 24, 305-310.

[21] Ellman, G.L. (1959) Tissue Sulfhydryl Groups. Archives of Biochemistry and Biophysique, 82, 70-77. https://doi.org/10.1016/0003-9861(59)90090-6

[22] Sinha, A.K. (1972) Colorimetric Assay of Catalase. Annals of Biochemistry, 47, 389-394. https://doi.org/10.1016/0003-2697(72)90132-7

[23] Misra, H. and Fridovich, I. (1972) The Role of Superoxide Anion in the Autoxidation of Epinephrine to Adrenochrome and A Simple Assay for Superoxide Dismutase. Journal of Biological Chemistry, 247, 3170-3175.

[24] Decker, K. and Keppler D. (1974) Galactosamine Hepatitis: Key Role of the Nucleotide Deficiency Period in the Pathogenesis of Cell Injury and Cell Death. In: Reviews of Physiology, Biochemistry and Pharmacology, Springer, Berlin, 77-106. https://doi.org/10.1007/BFb0027661

[25] Quintero, A., Pedraza, C.A., Siendones, E., Kamal, A.M., Elsaid, Colell, A., Garcia-Ruiz, C., Montero, J.L. De La Mata, M., Fernandez-Checa, J.C., Mino, G. and Muntane, J. (2002) PGE1 Protection against Apoptosis Induced by D-Galactosamine Is Not Related to the Modulation of Intracellular Free Radical Production in Primary Culture of Rat Hepatocytes. Free Radical Research, 36, 345-355.

https://doi.org/10.1080/10715760290019372

[26] Sandhyak, D., Gavitre, B.B., Gite, M.S., Akbar, A., Patil, M.D., Kulkarni, V. and Gaikwad, D.T. (2010) Evaluation of Hepatoprotective Activity of a Polyherbal Formulation (Phf-A) by Using Galactosamine-Induced Hepatotoxicity in Rats : A Resemblance of Human Viral Hepatitis. Journal of Pharmaceutical and Biomedical Sciences, 1, 1-5.

[27] Wang, H.P. and Li, Y. (2006) Protective Effect of Bicyclol on Acute Hepatic Failure Induced by Lipopolysaccharide and D-Galactosamine in Mice. European Journal of Pharmacology, 534, 194-201. https://doi.org/10.1016/j.ejphar.2005.12.080

[28] Guzik, T.J., Korbut, R. and Adamek-Guzik, T. (2003) Nitric Oxide and Superoxide 
in Inflammation and Immune Regulation. Journal of Physiology and Pharmacology, 54, 469-487.

[29] Hubert, D.J., Dawe, A., Florence, N.T., Gilbert, K.D., Angele, T.N., Buonocore, D., Finzi, P.V., Vidari, G. Bonaventure N.T., Marzatico F. and Paul, M.F. (2011) In Vitro Hepatoprotective and Antioxidant Activities of Crude Extract and Isolated Compounds from Ficus gnaphalocarpa. Inflammopharmacology, 19, 35-43. https://doi.org/10.1007/s10787-010-0070-4

[30] Maezona, K., Mawatari, K., Kajiwara, K., Shinkai, A. and Maki, T. (1996) Effect of Alanine on D-Galactosamine-Induced Acute Liver Failure in Rats. Hepatology, 24, 1211-1216. https://doi.org/10.1053/jhep.1996.v24.pm0008903400

[31] Wan, Y., Wu, Y.-L., Feng, X,-C., Lian, L.-H., Jiang, Y.-Z. and Nan, J.-X. (2010) the Protective Effects of Total Saponins from Ornithogalum saundersiae (Liliaceae) on Acute Hepatic Failure Induced by Lipopolysaccharide and D-Galactosamine in Mice. Journal of Ethnopharmacology, 132, 450-455.

https://doi.org/10.1016/j.jep.2010.08.025

[32] Drotman, R.B. and Lawhorn, G.T. (1978) Serum Enzymes as Indicators of Chemically Induced Liver Damage, Drug Chemistry and Toxicology, 1, 163-171. https://doi.org/10.3109/01480547809034433

[33] Johnston, D.E. (1999) Special Considerations in Interpreting Liver Function Tests. American Family Physician, 59, 2223-2230.

[34] Morikawa, A., Kato, Y., Sugiyama, T., Koide, N., Chakravortty, D., Yoshida, T. and Yokochi, T. (1999) Role of Nitric Oxide in Lipopolysaccharide-Induced Hepatic Injury in D-Galactosamine-Sensitized Mice as an Experimental Endotoxic Shock Model. Infection and Immunity, 67, 1018-1024. https://doi.org/10.1128/IAI.67.3.1018-1024.1999

[35] Moncada, S., Palmer, R.M. and Higgs, E.A. (1991) Nitric Oxide: Physiology, Pathophysiology, and Pharmacology. Pharmacology Review, 43, 109-142.

[36] Fotio, A.L., Olleros, M.L., Vesin, D., Tauzin, S., Bisig, R., Dimo, T., Nguelefack, T.B., Dongo, E., Kamtchouing, P. and Garcia, I. (2010) in Vitro Inhibition of LPS and Mycobacterium Bovis BCG-Induced Inflammatory Cytokines and in Vivo Protection from Gain/LPS-Mediated Liver Injury by the Medicinal Plant Sclerocarya birrea. International Journal of Immunopathology and Pharmacology, 23, 61-72. https://doi.org/10.1177/039463201002300106

[37] Szabo, C. (2003) Multiple Pathways of Peroxynitrite Cytotoxicity. Toxicology Letter, 141, 105-112. https://doi.org/10.1016/S0378-4274(02)00507-6

[38] Virag, L., Szabo, E., Gergely, P. and Szabo, C. (2003) Peroxynitrite-Induced Cytotoxicity: Mechanism and Opportunities for Intervention. Toxicology Letter, 140-141, 113-124. https://doi.org/10.1016/S0378-4274(02)00508-8

[39] Leki, N.Ć., Erný, D.Č., Ínek, A.H.O.̌̌., Provazník, Z., Martínek, J. and Farghali, H. (2011) Differential Oxidative Stress Responses to D-Galactosamine-Lipopolysaccharide Hepatotoxicity Based on Real Time PCR Analysis of Selected Oxidant/Antioxidant and Apoptotic Gene Expressions in Rat. Physiology Research, 60, 549-558. 